\title{
Soil Carbon Stocks under Amazonian Forest: Distribution in the Soil Fractions and Vulnerability to Emission
}

\author{
Jean Dalmo de Oliveira Marques ${ }^{1 *}$, Flávio Jesus Luizão² ${ }^{2}$ Wenceslau Geraldes Teixeira ${ }^{3}$, \\ Euler Melo Nogueira², Philip Martin Fearnside², Max Sarrazin ${ }^{4}$
}

\begin{abstract}
${ }^{1}$ Federal Institute of Education, Science and Technology of the Amazonas (IFAM), Campus Center of Manaus, Manaus, Brazil
${ }^{2}$ National Institute for Research in Amazonia (INPA), Manaus, Brazil

${ }^{3}$ National Center for Soil Research, Brazilian Agricultural Research Corporation (EMBRAPA), Rio de Janeiro, Brazil ${ }^{4}$ IRD, UMR BIOEMCO, Route de Montabo, Cayenne Cedex, French Guiana

Email: `jdomarques@hotmail.com, ^jeanmarques@ifam.edu.br, fluizao@inpa.gov.br, euler@inpa.gov.br, pmfearn@inpa.gov.br, wenceslau.teixeira@embrapa.com.br, max.sarrazin@ird.fr
\end{abstract}

How to cite this paper: de Oliveira Marques, J. D., Luizão, F. J., Teixeira, W. G., Nogueira, E. M., Fearnside, P. M., \& Sarrazin, M. (2017). Soil Carbon Stocks under Amazonian Forest: Distribution in the Soil Fractions and Vulnerability to Emission. Open Journal of Forestry, 7, 121-142. https://doi.org/10.4236/ojf.2017.72008

Received: November 7, 2016

Accepted: March 25, 2017

Published: March 28, 2017

Copyright $\odot 2017$ by authors and Scientific Research Publishing Inc. This work is licensed under the Creative Commons Attribution International License (CC BY 4.0).

http://creativecommons.org/licenses/by/4.0/

\begin{abstract}
Transformations of natural ecosystems in tropical regions, which are usually covered by high-biomass forests, contribute to increased atmospheric $\mathrm{CO}_{2}$. Much of the carbon in forest ecosystems is stored in the soil. This study estimates soil carbon stock in a dense forest in central Amazonia from sets of soil samples collected in three topographic positions (plateau, slope and valley bottom). Soil organic matter (SOM) was fractionated by density and particle size, thus obtaining the free light fraction (FLF), intra-aggregated light fraction (IALF), sand fraction (F-sand), clay fraction (F-clay) and silt fraction (F-silt). Soil organic carbon (SOC) stocks on the plateaus (Oxisol), slopes (Ultisol) and valley bottoms (Spodosol) were $98.4 \pm 7.8 \mathrm{Mg} \cdot \mathrm{ha}^{-1}$, $72.6 \pm 5.4 \mathrm{Mg} \cdot \mathrm{ha}^{-1}$ and $81.4 \pm 8.9 \mathrm{Mg} \cdot \mathrm{ha}^{-1}$, respectively. Distribution of carbon in soil fractions was: $112.6 \pm 15 \mathrm{Mg} \cdot \mathrm{ha}^{-1}$ (FLF), $2.5 \pm 0 \mathrm{Mg} \cdot \mathrm{ha}^{-1}$ (ILAF), $40.5 \pm 1.5 \mathrm{Mg} \cdot \mathrm{ha}^{-1}$ (F-silt), $68.5 \pm 4.2 \mathrm{Mg} \cdot \mathrm{ha}^{-1}$ (F-clay) and $28.3 \pm 1.4 \mathrm{Mg} \cdot \mathrm{ha}^{-1}$ (F-sand), totaling $252.4 \pm 22.1 \mathrm{Mg} \cdot \mathrm{ha}^{-1}$ of carbon. Carbon is largely in labile form and near the soil surface, making it liable to release from deforestation or from climate change. Spodosols are more susceptible to soil carbon losses, demonstrating the need to preserve forested areas close to Amazonian rivers and streams.
\end{abstract}

\section{Keywords}

Fractionation of Carbon, Carbon Stocks, Soil Physics, Global Warming, Amazon Rainforest, Brazil 


\section{Introduction}

Amazon forest stocks large quantities of carbon both in plant biomass (Nogueira et al., 2015) and in soil (Fearnside, 2016; Marques et al., 2016). Deforestation has accelerated the process of forest fragmentation in the brazilian amazon, resulting in changes in carbon stocks in both biomass and soil (Barros and Fearnside, 2016). Soil carbon under Amazonian forests has important roles in global change, making information on the forms and depths of these stocks of considerable interest in efforts to quantify emissions when deforestation converts these forests into pasture or other land uses. Information on these stocks is also important in evaluating the risk of this carbon being released to the atmosphere under projected climate scenarios. Carbon in labile fractions is the most susceptible to release if exposed to these perturbations, and carbon in any given form located near the soil surface is more likely to be released than carbon in deeper layers.

Maintaining carbon stocks in tropical forests in Amazonia and elsewhere has increasingly become a justification for governments to take measures to keep these forests standing rather than allowing them to be deforested. This is a key part of Brazil's strategy for REDD (Reducing Emissions from Deforestation and Degradation) (Brazil, CIMC, 2008; Brazil, MMA, 2009). From the standpoint of government policies, managing Amazonian forests for timber is increasingly seen as a means of maintaining the environmental services of the managed forest, including avoiding greenhouse-gas emissions, rather than primarily a means of earning revenue from timber sale (e.g., Fearnside, 1989, 2003). The carbon stocks in question include not only those in forest biomass, but also in the soil. Forests cleared for cattle pasture, which is the predominant land use in deforested areas in Brazilian Amazonia, lose substantial amounts of soil carbon under typical management (Fearnside and Barbosa, 1998).

Contrary to common perception, most of Amazonia is not flat. Instead, the landscape is dissected into a sequence of valleys and slopes, separated by plateau areas. Soils on these topographic features have different physical properties, soil being sandier in valley bottoms and with high clay content on plateaus (Chauvel, 1982; Fearnside and Leal Filho, 2001; Quesada et al., 2012). These differences are linked to differences in soil carbon, as well as to other factors in soil fertility.

Absorption and storage of carbon make natural ecosystems important in averting global climate change (Houghton, 2005). Among biosphere reservoirs, soil stands out for its carbon stock, especially in the form of organic matter. This totals approximately $1500-2000 \mathrm{Pg}$ carbon $\left(1 \mathrm{Pg}=1\right.$ Petagram $=10^{15} \mathrm{~g}=10^{9}$ $\mathrm{Mg}$ or metric tons), which corresponds to an amount of carbon two or three times greater than the existing terrestrial vegetation (Follett, 2001; Jobággy and Jackson, 2000).

Soil organic matter (SOM) is produced as a "waste" product of the biota, mainly of plants that partially decompose, supplying the raw material from which the organic matter is synthesized in various stages of structural diversity and complexity (Batjes and Dijkshoorn, 1999). SOM can also be defined as the 
totality of the organic carbon in the soil, with different structural conformations that result in labile and stable constituents (Passos et al., 2007). Stability of SOM is related to soil attributes such as physical protection of organic matter through the action of pores, aggregates, and interaction of surface minerals with organic molecules, as well as the relationship of SOM with the properties of terrestrial ecosystems that are associated with physical, chemical and biological processes (Chen et al., 2004).

Due to its complexity and structural diversity (Clapp and Hayes, 1999) and the possibilities for interaction with the soil mineral matrix (Hassink and Whitmore, 1997).

The understanding of SOM dynamics should not be restricted to total organic carbon. SOM is not a simple homogeneous component (Roscoe and Machado, 2002). SOM has various compartments, which have heterogeneous features. These include a living component (comprised mainly of microfauna), soil microorganisms, and a dead component. This dead component can be further sub-divided into the free light fraction (FLF), or macro-organic matter, intra-aggregate light fraction (IALF) and the heavy fraction. The FLF is most sensitive to changes caused by management, since it is composed of plant residues and other labile components that are quickly depleted after removing the top layers (Zech et al., 1997), while the IALF and the heavy fraction are protected by aggregates and soil particles.

However, despite the importance, there are few studies that can quantify the carbon contained in the soil fractions under primary forest. Recently in Brazil, several authors has investigated the carbon stocks in soil organic matter (SOM) under áreas of substitution of native Cerrado vegetation by agroecosystems (Ferreira et al., 2016), about disturbed wetlands of the Cerrado biome (Souza et al., 2015), about carbon stocks under areas primary forestry (Marques et al., 2016), to evaluate changes in SOM after organic compost application (Silva et al., 2016) and changes in soil total organic $C$ content and labile organic matter fractions in response to cover crop cultivation in an orange orchard (Oliveira et al., 2016a) and changes in soil organic carbon fractions to sugarcane planting due expansion of sugarcane into pastures (Olaya et al., 2016; Oliveira et al., 2016b; Signor et al., 2014).

The present study aimed to determine the quality and quantity of organic carbon in the different fractions of soil organic matter under rainforest along a topographic gradient. Such studies are important because they provide information about the distribution of carbon in soil fractions and about the soil attributes that directly influence carbon dynamics. This information is needed to reduce the uncertainty surrounding potential carbon emissions if forests are removed or if they are subjected to projected climate change.

\section{Methods}

\subsection{Study Area}

The study area is located on the Cuieiras Biological Reserve of the Instituto Na- 
cional de Pesquisas da Amazônia (INPA). The reserve covers an area of approximately 22.700 ha, located $60 \mathrm{~km}$ north of Manaus, Amazonas, Brazil (Figure 1). The site is at kilometer 34 on the ZF-2 service road (approximate geographical coordinates: $2^{\circ} 35^{\prime} 21.08^{\prime \prime} \mathrm{S}$ and $\left.60^{\circ} 6^{\prime} 53.63^{\prime \prime} \mathrm{W}\right)$. In this area the climate is tropical monsoonal (Koppen Am climate), with an annual average temperature of $26^{\circ} \mathrm{C}$ and relative humidity of about $84 \%$. Wind speeds are low throughout the year and winds blow mainly from the NE to SE directions. The wet season extends from November to May, and the dry season from June to October, with an average anual rainfall (1966-1992) of $2442 \mathrm{~mm}$, with a standard deviation of $306 \mathrm{~mm}$. Although rainfall occurs throughout the year, seasonal variation exists with higher rainfall between November and May than in the period from June to October (Waterloo et al., 2004).

Vegetation in the reserve is "dense ombrophilous forest" that is considered to be primary (not disturbed by non-indigenous occupation). The reserve is distributed between two basins: the Cuieiras River basin (13,414 ha) to the West and the Tarumã-Açu River basin (9321 ha) to the East (Ranzani, 1980). The topography of the transect included in this study covers a sequence of plateau (oxisol), slope (Ultisol) and valley (Spodosol) bottom (Luizão et al., 2004). Three plots (each $20 \times 40 \mathrm{~m}$ ) were established at each topographical position. In each plot samples were collected of the soil layers (0 - 5, 5 - 10, 10 - 20, 20 - 40, 40 $60,60-80,80-100,100-160,160-200 \mathrm{~cm}$ ) for analysis of soil organic carbon (SOC), carbon stock and soil physical attributes. In the valley (Spodosol) due to interference of ground water, the soil samples were collected to $1.0 \mathrm{~m}$ depht.

\subsection{Analysis and Stocks Carbon in Soil}

Total carbon analyses were determined by gas chromatography carried out with a Fisons Instruments analyzer (model NA 1500 NC) using approximately 25 - 30 $\mathrm{mg}$ of material that had been previously macerated with a mortar and pestle and
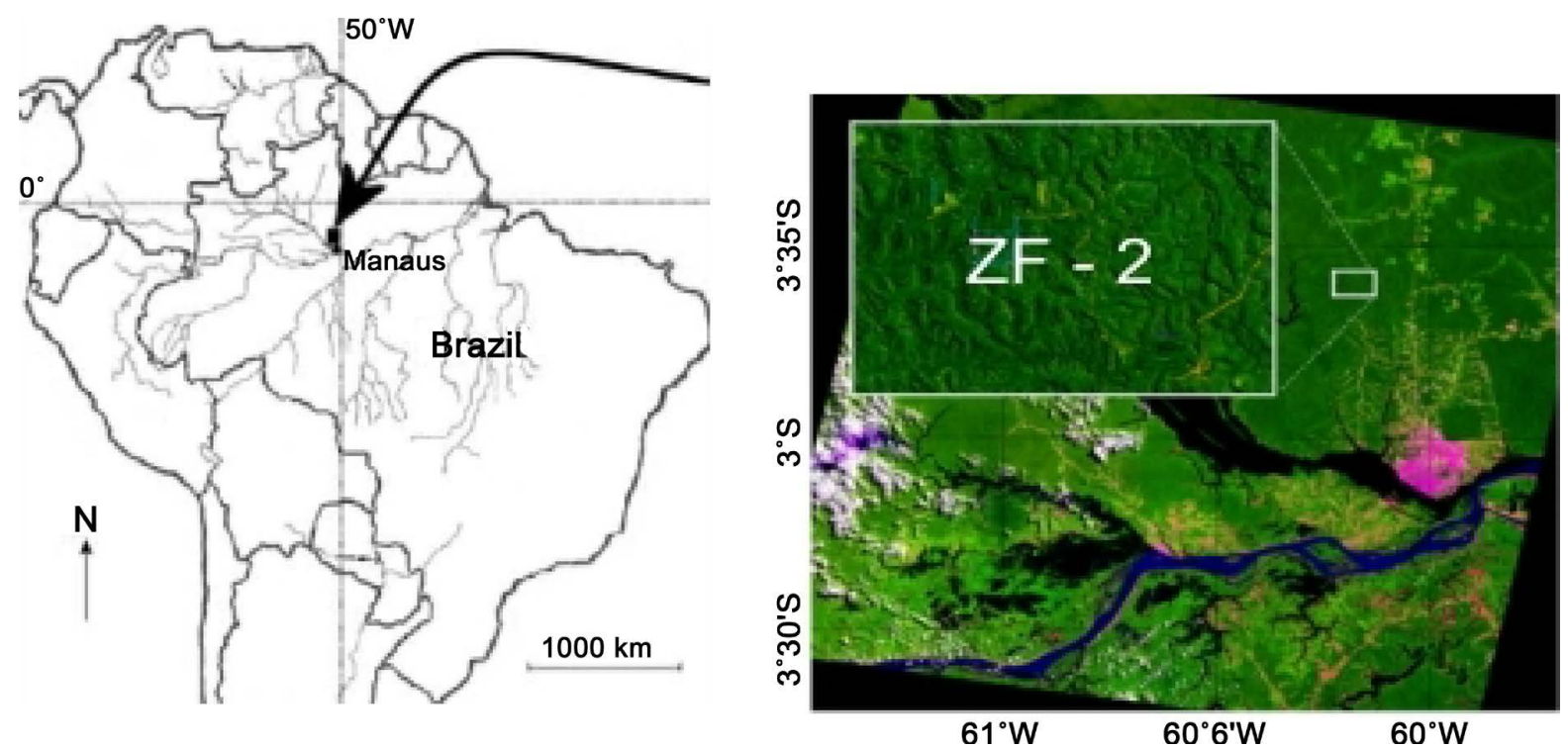

Figure 1. Location of the study area (Cuieiras Biological Reserve) in central Amazonia. 
passed through a $212-\mu \mathrm{m}$ mesh sieve in order to reduce errors associated with grain size. Carbon concentrations in soil $\left(\mathrm{C}, \mathrm{kg} \mathrm{m}^{-2}\right)$ were converted to total carbon stocks (CS, $\mathrm{Mg} \mathrm{ha}^{-1}$ ). Carbon stocks in each soil layer $\left(\mathrm{C}, \mathrm{Mg} \mathrm{ha}^{-1}\right)$ from the organic matter fractionation were obtained by multiplying the $\mathrm{C}$ concentration $\left(\mathrm{g} \mathrm{kg}^{-1}\right)$ by soil bulk density $\left(\rho, \mathrm{kg} \mathrm{m}^{-3}\right)$ and the thickness of the soil layer (h, $\mathrm{cm}$ ) (Equation (1)).

$$
\mathrm{CS}\left(\mathrm{Mg} \mathrm{ha}^{-1}\right)=\mathrm{C}\left(\mathrm{g} \mathrm{kg}^{-1}\right) \times \rho\left(\mathrm{kg} \mathrm{m}^{-3}\right) \times \mathrm{h}(\mathrm{cm})
$$

Carbon stocks $\left(\mathrm{Mg} \mathrm{ha}^{-1}\right)$ up to 2-m depth were calculated by adding the carbon stocks of the fractions. Calculations of carbon stocks were made by mass equivalency of the reference area (Sisti et al., 2004).

\subsection{Fractionation of Soil Organic Matter}

Samples selected for fractionation of SOM were analyzed according to the methodology proposed by Sohi et al. (2001), with the changes required for tropical soils (Campos, 2003; Roscoe and Machado, 2002). Fractionation of SOM was carried out through both densiometric fractionation and granulometric fractionation. In densiometric fractionation, 5-g of air-dried soil were weighed in 50 $\mathrm{mL}$ centrifuge flasks, with three repetitions for each sample, adding $35 \mathrm{~mL}$ de sodium iodide (NaI, $\mathrm{d}=1.80 \mathrm{~g} \mathrm{~cm}^{-3}$ ) to each flask. Flasks were hand-shaken for 30 seconds so that less-dense organic fractions remained on the surface of the solution and consequently promoted dispersion of unstable aggregates. Subsequently, flasks (soil $+\mathrm{NaI}$ ) were centrifuged for 30 minutes to allow settling of mineral particles to the bottom and the flasks were left resting for 24 hours. The overflowing organic fraction that had remained in solution (free light fraction) was removed by suction together with the NaI solution, and immediately separated by vacuum filtration (Millipore Sterifil aseptic system, $47 \mathrm{~mm}$ ) with previously weighed fiberglass filters ( $47 \mathrm{~mm}$ in diameter; $2 \mu \mathrm{m}$-Whatman GF/A type, lot 1820047). The filtered NaI solution was returned to the flask containing the remaining soil and the collected samples were washed with distilled water in order to eliminate excess NaI present in the fraction and in the filter. The organic fraction and the filter were later weighed and macerated in a porcelain crucible $(50 \mathrm{~mm}$ in diameter) until they reached the particle size of talc $(212 \mu \mathrm{m}$ mesh sieve).

After removal of the free light fraction (FLF), the intra-aggregate light fraction (IALF) (occluded fraction) was extracted. Ultrasound vibration was applied for 3 minutes using a Sonifier (model 250/450 cell disruptor) with 1-second pulsation intervals and an energy level of 206 to $400 \mathrm{~J} \mathrm{~mL}^{-1}$ in the NaI solution. Energy levels between 260 and $275 \mathrm{~J} \mathrm{~mL}^{-1}$ are sufficient to provide dispersion of soil samples (Roscoe and Buurman, 2000). After sonification, centrifugation was performed and samples were left to rest for 36 hours. IALF that had collected in the filters was then dried, weighed and ground in the same way as was done for the FLF. Three laboratory replicates were obtained from each fraction and were mixed to form a single composite sample for determination of total carbon and nitrogen by dry combustion (Sohi et al., 2001). 
In granulometric fractionation, organic matter from the sand fraction (Fsand) $(>53 \mu \mathrm{m})$ was obtained by wet sieving, while organic matter from the silt fraction (F-silt) $(2-53 \mu \mathrm{m})$ and the clay fraction (F-clay) $(0-2 \mu \mathrm{m})$ were determined by collecting aliquots of the $0-2 \mu \mathrm{m}$ and $2-53 \mu \mathrm{m}$ granulometric fractions, which were separated by sedimentation. Each fraction was later placed in a desiccator, weighed, stored in a previously labeled flask and kept in an oven at $60^{\circ} \mathrm{C}$ to avoid moisture absorption. Samples were then ground to powder for subsequent dry analysis using a Perkin Elmer CHN autoanalyzer.

\subsection{Analysis of Soil Physical Properties}

Granulometric analysis was performed by the pipette method (Brazil, EMBRAPA, 1997). Soil density was determined in undisturbed samples collected with an Uhland-type sampler, with volumetric rings $0.05 \mathrm{~m}$ in height and $0.05 \mathrm{~m}$ in diameter. Sampling was done in quintuplicate throughout the selected layers. Analysis of the stability of aggregates was performed on six soil samples collected at the soil surface to $10-\mathrm{cm}$ depth (plateau [Oxisol] and slope [Ultisol]), along the topographical gradient; this was not done for the valley bottoms because the structure of the soil does not allow formation of aggregates. Pore size distribution was determined in the samples used to obtain soil density, with separation between macro-and micro-pores being defined by draining at $6-\mathrm{kPa}$ tension. Total porosity was calculated from the relationship between soil density and particle density (Brazil, EMBRAPA, 1997).

\subsection{Corrections for Estimating Soil Carbon Emission to the Atmosphere}

The carbon stock in any soil is the result of a balance between inflows and outflows of carbon. In tropical soils, the rates of both carbon inflow and outflow are substantially higher than is the case in other parts of the world, making tropical soil carbon stocks respond rapidly to any changes in the flux rates. Estimation of soil carbon emission to the atmosphere from each soil depth was based on the sequence of transformations between land uses after following deforestation (such as agriculture, pasture and secondary forest) derived by Fearnside and Barbosa (1998). The carbon losses derived from this are believed to be conservative: 7.5\%, $5.6 \%$ and $0.4 \%$ in layers from 0 to $20 \mathrm{~cm}, 20$ to $100 \mathrm{~cm}$ and 100 to $200 \mathrm{~cm}$ depth, respectively, assuming that the new equilibrium environment is a degraded pasture.

\subsection{Data Analysis}

Data on soil physical attributes of carbon stocks and fractions at each topographic position (plateau, slope and valley) were subjected to one-way analysis of variance (ANOVA). Depths were compared along each topographic gradient and the fractions were considered to determine the quality and quantity of organic $\mathrm{C}$ in different compartments of the soil. Means were compared using the Tukey HSD test for variables for which the F-test was significant $(p<0.05)$. 


\section{Results}

\subsection{Distribution of Carbon Fractions in Soil Layers}

Carbon concentrations in surface layers $(0-5,5-10,10-20$ and $20-40 \mathrm{~cm})$ were higher in the free light fraction than in the heavy fractions (F-clay, F-silt and $\mathrm{F}$-sand). However, at greater depths the clay fraction retained more carbon. In general, levels of carbon in the soil in more labile fractions (FLF and IALF) decreased with depth along the topographical gradient because only the surface horizons are enriched in carbon through their proximity to the accumulations of litter. Most soil carbon present in surface layers is associated with the free light fraction (FLF), ranging from $26 \%$ to $57 \%$ on the plateau (Figure 2 (a)), from $20 \%$ to $80 \%$, on the slope (Figure 2(b)) and $49 \%$ to $66 \%$ in the valley bottom (Figure $2(\mathrm{c}))$. On the other hand, at depth carbon in the heavy fraction (clay) was responsible for $66 \%$ to $80 \%$ of the total on the plateau (Figure 2 (a)), $56 \%$ to $74 \%$ on the slope (Figure 2 (b)) and $0.5 \%$ to $2.5 \%$ in the valley (Figure $2(\mathrm{c})$ ).

\subsection{Carbon Stocks in Soil Fractions}

Soil carbon quantities in fractions of organic matter (FLF, IALF, F-clay, F-silt and F-sand) were different among topographic positions and depths in the soil (Figures 3-5). In Oxisol the largest carbon stocks are present at 5-cm depth in FLF (16.7 $\mathrm{Mg} \mathrm{ha}^{-1}$ ) and F-clay (15.0 $\mathrm{Mg} \mathrm{ha}^{-1}$ ) (Figure 3); stocks decrease with depth. In Ultisol the greatest carbon stocks were also observed in the 5-cm layer in FLF (19.7 Mg ha ${ }^{-1}$ ) (Figure 4), in contrast to Oxisol (Figure 3). In Spodosol, the largest carbon stocks occurred in the FLF that was present in the surface layers (0 - 5, 5 - 10, $10-20$ and $20-40 \mathrm{~cm}$ ), with C stocks of $31.8 \mathrm{Mg} \mathrm{ha}^{-1}, 17.8 \mathrm{Mg}$ $\mathrm{ha}^{-1}, 6.8 \mathrm{Mg} \mathrm{ha}^{-1}$ and $6.6 \mathrm{Mg} \mathrm{ha}^{-1}$, respectively (Figure 5); these stocks surpassed those contained in Oxisol (Figure 3 ) and Ultisol (Figure 4).

\subsection{Total Carbon Stocks in Fractions in Each Soil Class}

The greatest total $\mathrm{C}$ stocks in soil fractions were, in decreasing order: Oxisol (plateau) (98.4 $\left.\pm 15 \mathrm{Mg} \mathrm{ha}^{-1}\right)$, Ultisol (slope) $\left(72.6 \pm 5.4 \mathrm{Mg} \mathrm{ha}^{-1}\right.$ ) and Spodosol (valley) $\left(81.4 \pm 8.9 \mathrm{Mg} \mathrm{ha}^{-1}\right)$; there was significant difference between them.

The FLF stocks were $23.1 \pm 3.3 \mathrm{Mg} \mathrm{ha}^{-1}, 26.3 \pm 3.9 \mathrm{Mg} \mathrm{ha}^{-1}$ and $63.2 \pm 7.8 \mathrm{Mg}$ $\mathrm{ha}^{-1}$, in the plateau (Oxisol), slope (Ultisol) and valley (Spodosol), respectively (Table 1). The IALF stocks were $0.4 \pm 0 \mathrm{Mg} \mathrm{ha}^{-1}, 1.0 \pm 0 \mathrm{Mg} \mathrm{ha}^{-1}$ and $1.1 \pm 0 \mathrm{Mg}$ $\mathrm{ha}^{-1}$ in the plateau (Oxisol), slope (Ultisol) and valley (Spodosol), respectively (Table 1). The total carbon emission potential of FLF and IALF is $15.5 \pm 2.3 \mathrm{Mg}$ $\mathrm{ha}^{-1}$.

The largest stocks of carbon in the heavy fraction are stored in clay in plateau soils $\left(53.4 \pm 3.5 \mathrm{Mg} \mathrm{ha}^{-1}\right)$, while in slope soils most is stored in F-silt $(21.2 \pm 0.7$ $\mathrm{Mg} \mathrm{ha}^{-1}$ of C) and in valley bottom soils most is in F-sand (10.0 $\left.\pm 0.6 \mathrm{Mg} \mathrm{ha}^{-1}\right)$. Considering the heavy fractions (F-clay, F-silt and F-sand), the potential emissions from these fractions are: $9.2 \pm 0.5 \mathrm{Mg} \mathrm{ha}^{-1}, 5.4 \pm 0.2 \mathrm{Mg} \mathrm{ha}^{-1}$ and $3.82 \pm 0.1$ $\mathrm{Mg} \mathrm{ha}^{-1}$, respectively (Table 1 ). 


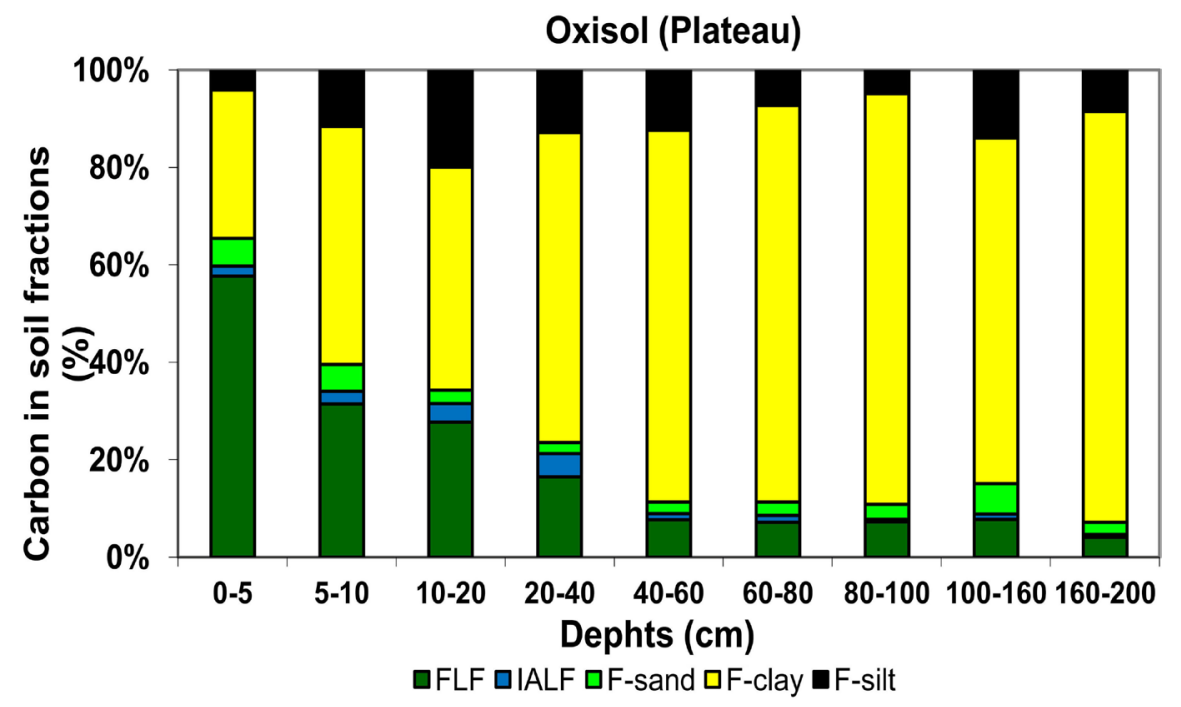

(a)

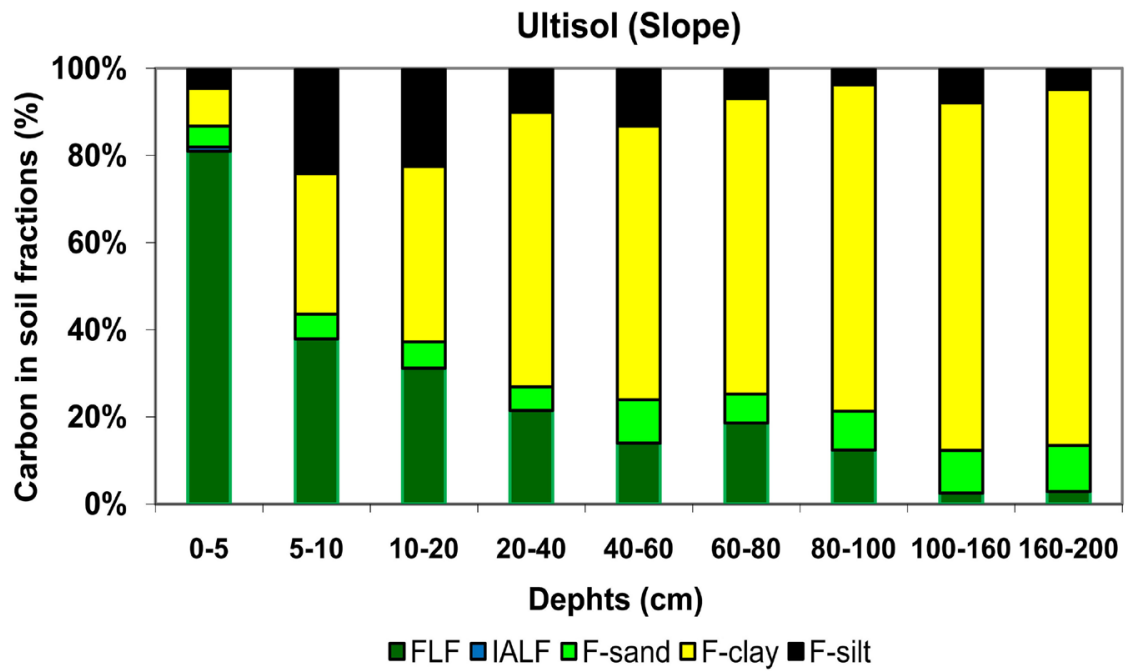

(b)

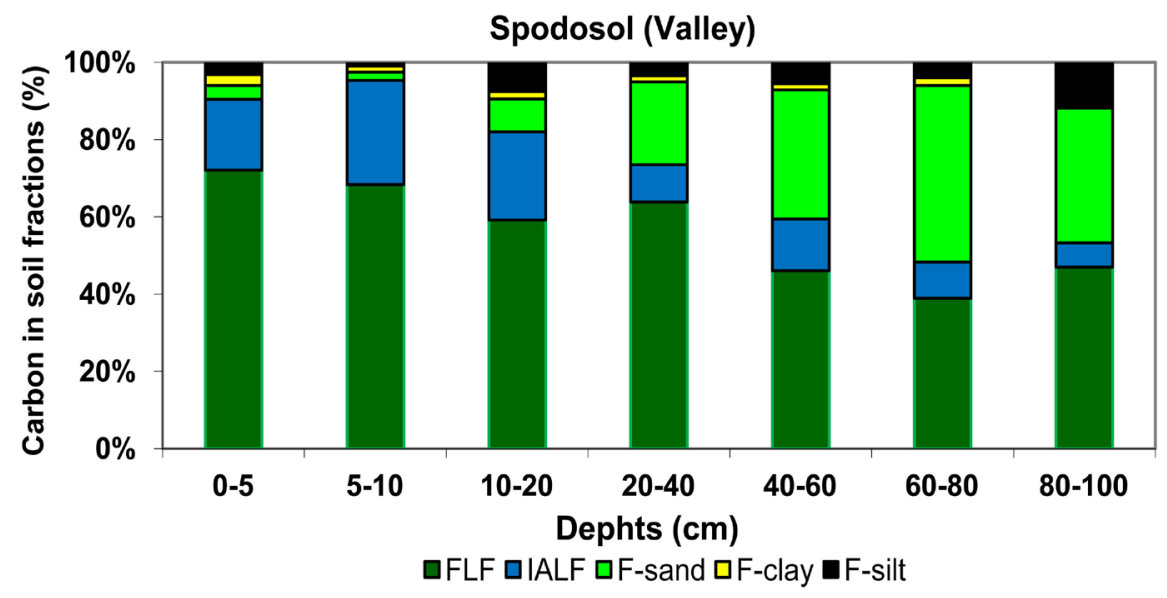

(c)

Figure 2. Carbon contents in soil fractions in three topographic positions in dense forest in central Amazonia. (a) = plateau (Oxisol), (b) = slope (Ultisol), (c) = valley bottom (Spodosol). 


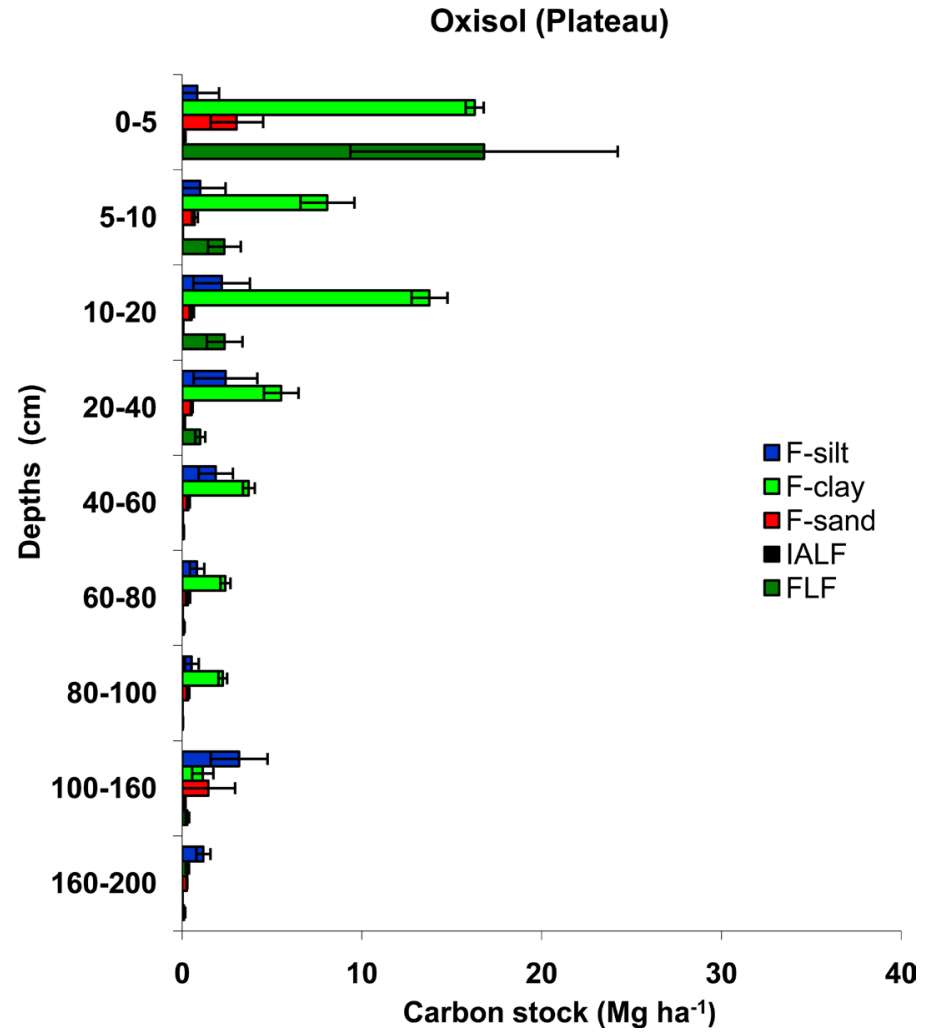

Figure 3. Carbon stocks in light and heavy fractions on the plateau (Oxisol). Values correspond to the average of five soil profiles $(n=5)$, with their respective standard deviations represented by the horizontal lines.

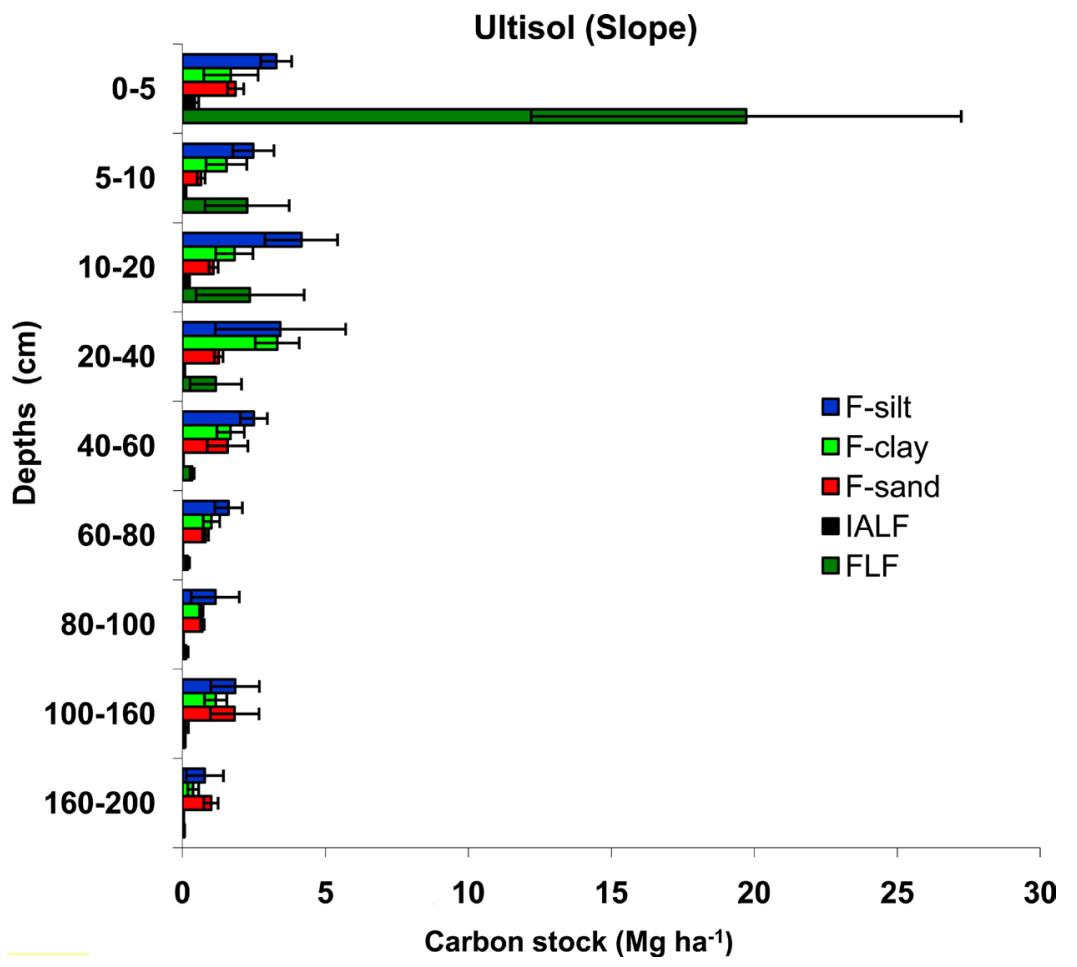

Figure 4. Carbon stocks in light and heavy fractions on the slopes (Ultisol). Values correspond to the average of five soil profiles $(n=5)$, with their respective standard deviations represented by the horizontal lines. 


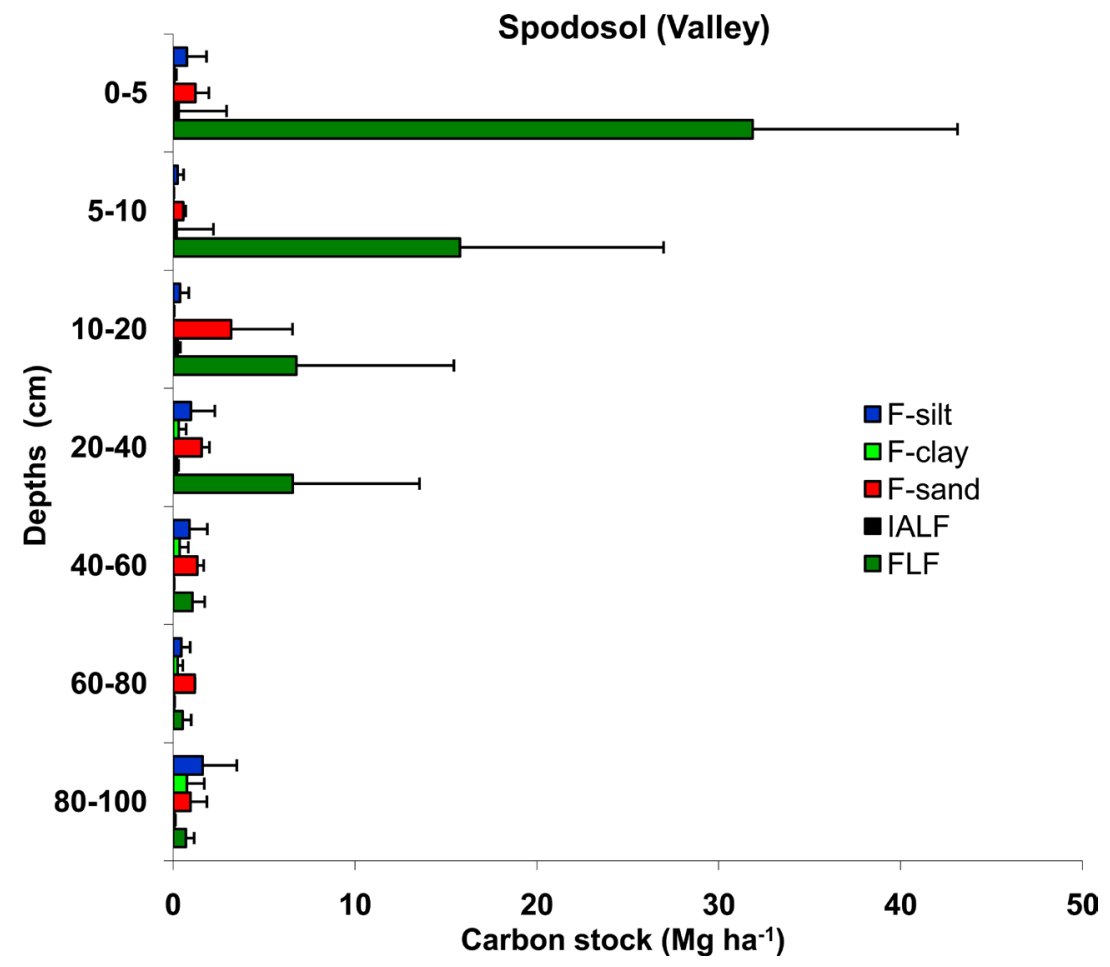

Figure 5. Carbon stocks in light and heavy fractions in the valley bottoms (Spodosol). Values correspond to the average of five soil profiles $(n=5)$, with their respective standard deviations represented by the horizontal lines.

Table 1. Total carbon stocks $\left(\mathrm{Mg} \mathrm{ha}^{-1}\right)$ in soil organic matter fractions up to 2-m depth at three topographic positions.

\begin{tabular}{cccccccc}
\hline Position & Soil & FLF & IALF & F-Silt & F-Clay & F-Sand & Total \\
\hline Plateau & Oxisol & $23.1( \pm 3.3) \mathrm{b}$ & $0.4( \pm 0) \mathrm{b}$ & $14.0( \pm 0.5) \mathrm{b}$ & $53.4( \pm 3.5) \mathrm{a}$ & $7.5( \pm 0.5) \mathrm{b}$ & $98.4( \pm 7.8) \mathrm{a}$ \\
Slope & Ultisol & $26.3( \pm 3.9) \mathrm{b}$ & $1.0( \pm 0) \mathrm{a}$ & $21.2( \pm 0.7) \mathrm{a}$ & $13.3( \pm 0.5) \mathrm{b}$ & $10.8( \pm 0.3) \mathrm{a}$ & $72.6( \pm 5.4) \mathrm{b}$ \\
Valley & Spodosol & $63.2( \pm 7.8) \mathrm{a}$ & $1.1( \pm 0) \mathrm{a}$ & $5.3( \pm 0.3) \mathrm{c}$ & $1.8( \pm 0.2) \mathrm{c}$ & $10.0( \pm 0.6) \mathrm{a}$ & $81.4( \pm 8.9) \mathrm{c}$ \\
Total & - & $112.6( \pm 15)$ & $2.5( \pm 0)$ & $40.5( \pm 1.5)$ & $68.5( \pm 4.2)$ & $28.3( \pm 1.4)$ & $252.4( \pm 22.1)$ \\
\hline
\end{tabular}

FLF $=$ Free light fraction, IALF $=$ intra-aggregate light fraction, F-Silt $=$ silt fraction, F-Clay $=$ clay fraction, F-sand $=$ sand fraction. Comparisons between means (Tukey test HSD). Values followed by the same letter in the same column are not significantly different by the F-test in an analysis of variance ( $\mathrm{p}$ 0.05).

\subsection{Soil Physical Characteristics and SOC in Each Soil Layers}

On the plateau (Oxisol), granulometric analysis revealed clay contents of $686.5 \mathrm{~g}$ $\mathrm{kg}^{-1}$ on the surface and of $868.5 \mathrm{~g} \mathrm{~kg}^{-1}$ to $2.0 \mathrm{~m}$ depth, indicating a very clayey texture (Table 2). Ultisol (slope) had between $309.3 \mathrm{~g} \mathrm{~kg}^{-1}$ and $482 \mathrm{~g} \mathrm{~kg}^{-1}$ of clay. The valley bottoms (Spodosol) had a different dynamic, with illuviation of organic matter concentrated on the spodic horizon to $120 \mathrm{~cm}$ depth and with $9.3 \mathrm{~g}$ $\mathrm{kg}^{-1}$ to $17.5 \mathrm{~g} \mathrm{~kg}^{-1}$ of clay. Soil densities ranged from $1.0 \mathrm{~g} \mathrm{~cm}^{-3}$ to $1.2 \mathrm{~g} \mathrm{~cm}^{-3}$ on the plateau (Oxisol), increasing on the slope (Ultisol) to $1.2 \mathrm{~g} \mathrm{~cm}^{-3}$ to $1.6 \mathrm{~g} \mathrm{~cm}^{-3}$ and in the valley bottom (Spodosol) reaching values between $1.4 \mathrm{~g} \mathrm{~cm}^{-3}$ and $1.7 \mathrm{~g}$ $\mathrm{cm}^{-3}$ (Table 2). The soils have total porosity above $0.36 \mathrm{~m}^{-3} \mathrm{~m}^{-3}$ and have less macropores than micropores. Ultisol (slope), had macroporosity varying between $0.1 \mathrm{~m}^{-3} \mathrm{~m}^{-3}$ and $0.4 \mathrm{~m}^{-3} \mathrm{~m}^{-3}$, while the Oxisol (plateau) had the greatest 
Table 2. Total values of soil organic carbon (SOC), clay content, soil density, total porosity, macroporosity, microporosity along a topographic gradient in primary forest (Cueiras Biological Reserve, ZF2 road).

\begin{tabular}{|c|c|c|c|c|c|c|}
\hline Position & $\begin{array}{c}\mathrm{SOC} \\
\left(\mathrm{g} \mathrm{kg}^{-1}\right)\end{array}$ & $\begin{array}{c}\text { Clay } \\
\left(\mathrm{g} \mathrm{kg}^{-1}\right)\end{array}$ & $\begin{array}{l}\text { Soil Density } \\
\left(\mathrm{m}^{-3} \mathrm{~m}^{-3}\right)\end{array}$ & $\begin{array}{l}\text { Total porosity } \\
\qquad\left(\mathrm{m}^{-3} \mathrm{~m}^{-3}\right)\end{array}$ & $\begin{array}{c}\text { Macropores } \\
\left(\mathrm{m}^{-3} \mathrm{~m}^{-3}\right)\end{array}$ & $\begin{array}{c}\text { Micropores } \\
\left(\mathrm{m}^{-3} \mathrm{~m}^{-3}\right)\end{array}$ \\
\hline \multicolumn{7}{|c|}{$0.00-0.05 \mathrm{~m}$} \\
\hline Plateau & $43.3( \pm 0.8) \mathrm{b}$ & $686.5( \pm 0.4) \mathrm{a}$ & $1.0( \pm 0.1) c$ & $0.5( \pm 0.2) \mathrm{a}$ & $0.2( \pm 0.2) \mathrm{b}$ & $0.3( \pm 0.2) \mathrm{b}$ \\
\hline Slope & $31.5( \pm 0.9) \mathrm{c}$ & $309.3( \pm 0.5) \mathrm{b}$ & $1.3( \pm 0.1) \mathrm{b}$ & $0.4( \pm 0.1) \mathrm{a}$ & $0.2( \pm 0.2) b$ & $0.2( \pm 0.2) \mathrm{b}$ \\
\hline Valley & $55.1( \pm 0.8) \mathrm{a}$ & $10.0( \pm 0.1) \mathrm{c}$ & $1.5( \pm 0.2) \mathrm{a}$ & $0.4( \pm 0.1) \mathrm{a}$ & $0.4( \pm 0.2) \mathrm{a}$ & $0.9( \pm 0.2) \mathrm{a}$ \\
\hline \multicolumn{7}{|c|}{$0.05-0.10 \mathrm{~m}$} \\
\hline Plateau & $35.9( \pm 0.0) \mathrm{b}$ & $703.2( \pm 0.9) \mathrm{a}$ & $1.0( \pm 0.1) \mathrm{c}$ & $0.5( \pm 0.2) \mathrm{a}$ & $0.1( \pm 0.2) b c$ & $0.4( \pm 0.2) \mathrm{b}$ \\
\hline Slope & $20.4( \pm 0.6) c$ & $311.3( \pm 0.2) \mathrm{b}$ & $1.3( \pm 0.1) \mathrm{b}$ & $0.4( \pm 0.1) \mathrm{a}$ & $0.2( \pm 0.2) \mathrm{b}$ & $0.2( \pm 0.1) c$ \\
\hline Valley & $37.8( \pm 0.5) \mathrm{a}$ & $14.7( \pm 0.0) \mathrm{c}$ & $1.5( \pm 0.2) \mathrm{a}$ & $0.4( \pm 0.1) \mathrm{a}$ & $0.3( \pm 0.2) \mathrm{a}$ & $0.9( \pm 0.2) \mathrm{a}$ \\
\hline \multicolumn{7}{|c|}{$0.10-0.20 \mathrm{~m}$} \\
\hline Plateau & $16.5( \pm 0.2) \mathrm{b}$ & $794.0( \pm 1.2) \mathrm{a}$ & $1.1( \pm 0.2) c$ & $0.6( \pm 0.2) \mathrm{a}$ & $0.1( \pm 0.2) \mathrm{b}$ & $0.5( \pm 0.2) b$ \\
\hline Slope & $15.6( \pm 0.5) c$ & $431.6( \pm 0.6) \mathrm{b}$ & $1.4( \pm 0.1) \mathrm{b}$ & $0.4( \pm 0.2) b$ & $0.1( \pm 0.2) \mathrm{b}$ & $0.3( \pm 0.1) c$ \\
\hline Valley & $20.8( \pm 0.4) \mathrm{a}$ & $17.5( \pm 0.0) \mathrm{c}$ & $1.5( \pm 0.1) \mathrm{a}$ & $0.4( \pm 0.1) b$ & $0.3( \pm 0.1) \mathrm{a}$ & $0.9( \pm 0.2) \mathrm{a}$ \\
\hline \multicolumn{7}{|c|}{$0.20-0.40 \mathrm{~m}$} \\
\hline Plateau & $9.6( \pm 0.0) \mathrm{a}$ & $828.0( \pm 0.2) \mathrm{a}$ & $1.1( \pm 0.1) c$ & $0.6( \pm 0.1) \mathrm{a}$ & $0.1( \pm 0.2) \mathrm{b}$ & $0.5( \pm 0.1) \mathrm{a}$ \\
\hline Slope & $8.3( \pm 0.7) \mathrm{b}$ & $433.6( \pm 0.8) \mathrm{b}$ & $1.5( \pm 0.1) \mathrm{b}$ & $0.4( \pm 0.1) b$ & $0.1( \pm 0.1) \mathrm{b}$ & $0.2( \pm 0.1) \mathrm{b}$ \\
\hline Valley & $8.2( \pm 0.0) b$ & $10.0( \pm 0.1) \mathrm{c}$ & $1.6( \pm 0.2) \mathrm{a}$ & $0.3( \pm 0.1) \mathrm{b}$ & $0.3( \pm 0.1) \mathrm{a}$ & $0.2( \pm 0.1) \mathrm{b}$ \\
\hline \multicolumn{7}{|c|}{$0.40-0.60 \mathrm{~m}$} \\
\hline Plateau & $6.4( \pm 0.0) \mathrm{a}$ & $811.4( \pm 0.1) \mathrm{a}$ & $1.1( \pm 0.1) c$ & $0.6( \pm 0.1) \mathrm{a}$ & $0.1( \pm 0.1) \mathrm{b}$ & $0.5( \pm 0.1) \mathrm{a}$ \\
\hline Slope & $6.3( \pm 0.1) \mathrm{a}$ & $469.3( \pm 0.3) \mathrm{b}$ & $1.3( \pm 0.1) \mathrm{b}$ & $0.5( \pm 0.1) \mathrm{a}$ & $0.2( \pm 0.1) \mathrm{ab}$ & $0.2( \pm 0.1) \mathrm{b}$ \\
\hline Valley & $5.9( \pm 0.4) \mathrm{a}$ & $10.0( \pm 0.0) \mathrm{c}$ & $1.5( \pm 0.1) \mathrm{a}$ & $0.3( \pm 0.1) b$ & $0.3( \pm 0.1) \mathrm{a}$ & $0.2( \pm 0.1) \mathrm{b}$ \\
\hline \multicolumn{7}{|c|}{$0.60-0.80 \mathrm{~m}$} \\
\hline Plateau & $4.7( \pm 0.0) \mathrm{b}$ & $802.7( \pm 0.0) \mathrm{a}$ & $1.2( \pm 0.2) b$ & $0.6( \pm 0.1) \mathrm{a}$ & $0.1( \pm 0.1) \mathrm{b}$ & $0.5( \pm 0.1) \mathrm{a}$ \\
\hline Slope & $3.9( \pm 0.0) \mathrm{b}$ & $472.5( \pm 0.9) \mathrm{b}$ & $1.3( \pm 0.1) \mathrm{b}$ & $0.4( \pm 0.1) b$ & $0.1( \pm 0.1) \mathrm{b}$ & $0.3( \pm 0.1) \mathrm{b}$ \\
\hline Valley & $5.1( \pm 0.3) \mathrm{a}$ & $10.0( \pm 0.2) \mathrm{c}$ & $1.5( \pm 0.1) \mathrm{a}$ & $0.3( \pm 0.1) \mathrm{b}$ & $0.3( \pm 0.1) \mathrm{a}$ & $0.2( \pm 0.1) \mathrm{b}$ \\
\hline \multicolumn{7}{|c|}{$0.80-1.00 \mathrm{~m}$} \\
\hline Plateau & $4.1( \pm 0.0) \mathrm{b}$ & $849.2( \pm 0.7) \mathrm{a}$ & $1.2( \pm 0.3) c$ & $0.6( \pm 0.1) \mathrm{a}$ & $0.1( \pm 0.1) \mathrm{ab}$ & $0.5( \pm 0.1) \mathrm{a}$ \\
\hline Slope & $3.3( \pm 0.0) c$ & $482.5( \pm 1.3) \mathrm{b}$ & $1.4( \pm 0.1) \mathrm{b}$ & $0.5( \pm 0.1) \mathrm{a}$ & $0.2( \pm 0.1) \mathrm{a}$ & $0.3( \pm 0.1) b$ \\
\hline Valley & $6.3( \pm 0.6) \mathrm{a}$ & $9.3( \pm 0.0) \mathrm{c}$ & $1.6( \pm 0.1) \mathrm{a}$ & $0.3( \pm 0.1) b$ & $0.3( \pm 0.1) \mathrm{a}$ & $0.3( \pm 0.1) \mathrm{b}$ \\
\hline \multicolumn{7}{|c|}{$1.00-1.60 \mathrm{~m}$} \\
\hline Plateau & $2.9( \pm 0.0) \mathrm{a}$ & $863.2( \pm 0.3) \mathrm{a}$ & $1.2( \pm 0.1) \mathrm{b}$ & $0.6( \pm 0.1) \mathrm{a}$ & $0.1( \pm 0.1) \mathrm{a}$ & $0.5( \pm 0.1) \mathrm{a}$ \\
\hline Slope & $2.4( \pm 0.0) \mathrm{a}$ & $464.8( \pm 0.3) \mathrm{b}$ & $1.5( \pm 0.2) \mathrm{a}$ & $0.5( \pm 0.1) \mathrm{a}$ & $0.2( \pm 0.1) \mathrm{a}$ & $0.3( \pm 0.1) \mathrm{b}$ \\
\hline Valley & - & - & - & - & - & - \\
\hline \multicolumn{7}{|c|}{$1.60-2.00 \mathrm{~m}$} \\
\hline Plateau & $2.0( \pm 0.0) \mathrm{a}$ & $868.5( \pm 0.5) \mathrm{a}$ & $1.2( \pm 0.1)$ & $0.6( \pm 0.1) \mathrm{a}$ & $0.1( \pm 0.1) \mathrm{a}$ & $0.5( \pm 0.1) \mathrm{a}$ \\
\hline Slope & $1.7( \pm 0.0) \mathrm{a}$ & $867.1( \pm 0.5) \mathrm{a}$ & $1.5( \pm 0.1)$ & $0.5( \pm 0.1) \mathrm{a}$ & $0.1( \pm 0.1) \mathrm{a}$ & $0.3( \pm 0.1) \mathrm{b}$ \\
\hline Valley & - & - & - & - & - & - \\
\hline
\end{tabular}

Means followed by the same letter in the columns do not differ at $5 \%$ by the Tukey test. Values in brackets refer to the confidence interval $(n=5)(\alpha=0.5)$. (-) sample not collected. 
quantities of micropores, ranging from $0.3 \mathrm{~m}^{-3} \mathrm{~m}^{-3}$ to $0.5 \mathrm{~m}^{-3} \mathrm{~m}^{-3}$. Spodosol (valley) had the highest macroporosity $\left(0.3 \mathrm{~m}^{-3} \mathrm{~m}^{-3}\right.$ to $\left.0.4 \mathrm{~m}^{-3} \mathrm{~m}^{-3}\right)$ (Table 2). The spodosol had the greatest quantities of SOC ranging from $20.8 \pm 0.4$ to $55.1 \pm 0.8$ $\mathrm{g} \mathrm{kg}^{-1}$ beteween 0.0 to 0.2 depht showing significant difference of other topographic position. From this depth, the differences are smaller, not as significant with contents ranging from $1.7 \pm 0.0$ to $9.6 \pm 0.0 \mathrm{~g} \mathrm{~kg}^{-1}$.

\section{Discussion}

\subsection{Physical Characteristics and Distribution of Organic Carbon}

Variations in physical characteristics of soils along the topographical gradient under primary forest influence distribution of organic carbon in physical fractions of soil organic matter (SOM). Modifications in these attributes can cause major changes in carbon stocks.

In Oxisol the high carbon stocks near the surface in FLF and their decrease with depth demonstrate the importance of litter (necromass), clay and soil density to the carbon stocks. Ultisol also had greatest carbon stocks in the surface layer in FLF, with the surface gaining relative importance from a drastic decrease in stock with depth that may be explained by the position of the soil in the landscape and by the soil physical characteristics. In Spodosol, rapid entry of carbon from incorporating decomposing litter, together with nutrient retention action by the interlacing of roots and high soil bulk density, result in greater stocks than in other soil types.

The FLF is more sensitive to inadequate management and this carbon is easily released from the soil (Smith, 2007), becoming an important fraction in the evaluation of quality management system in the short term (Bayer et al., 2001; Conceição et al., 2005). Greater clay content of soils in more-elevated topographic positions stabilizes and protects much of the carbon (Volkoff et al., 1984). Carbon in agroecosystems has been shown to have greater stability and preservation in the heavy fraction (Hassink and Whitmore, 1997). Carbon in the heavy fractions takes more time to be released, since this fraction is less sensitive to management.

The relations found are influenced by soil structure, mainly in the surface layers, and are promoted by the action of macrofauna that give rise to the biogenic structures and stable aggregates that modify the physical properties of soils (Lavelle et al., 1997). The structure of Amazonian soils under forest allows carbon to remain stored, avoiding losses to the atmosphere. The predominance of small pores we found may lead to slower carbon translocation, preventing decomposers from having access to the SOM and causing occlusion of the substrate inside the aggregates (Ekschmitt et al., 2005). Large pores, on the other hand, make movement of carbon faster, such that the carbon can move from one soil layer to another. Small pores retain carbon, causing slow movement through the soil layers due to the restricted diameters of the pores and their association with the surface of the clay (Marques et al., 2012). Other studies (Marques et al., $2008,2010)$ have shown the relationship between SOC and hydraulic properties, 
with greater levels of SOC to be associated with the action of fine roots in surface layers in forest soils in the lower Amazon. These studies have also shown influence of organic content on soil structure and aggregation, especially in the surface layers of the soil. Soil structure, although not a nutritional factor for plant growth, exerts direct influence on the movement of water and is one of the most important attributes for the adaptation of species; it can be evaluated through soil density, macro- and micro-porosity, aggregate stability, penetration resistance and permeability, among other factors (Tisdall and Oades, 1982). SOC content has been an efficient indicator because decrease in carbon content can be directly related to reduction of aggregate stability, among other reasons (Pinheiro et al., 2004).

Our results agree with other studies that demonstrate the importance of soil particle distribution in the control of soil carbon stocks (Lopez-Ulloa et al., 2005). Soil carbon stocks were greater in FLF and F-clay, stressing the importance of clay soils under primary forest in Amazonia in physical protection of soil carbon. Soils located in tropical forests usually feature high biological activity, providing increased carbon in FLF. This is dependent on decomposition rate, which is controlled by the primary recalcitrance of the litter (von Lutzow et al., 2006).

Another important factor in the distribution of carbon in physical fractions of soil is position in relation to topography. Position in the topographic gradient influences water dynamics, which, in turn, determine levels of organic matter fractions, especially FLF and IALF, which are transported by lateral flow and especially by water in the vertical relief (Canellas et al., 2000). In very clayey soils (Oxisols) (plateau), carbon is mainly stored in FLF near the surface and in F-clay at depth. In clay soils with medium texture (Ultisols) (slope), carbon is mainly stored in FLF near the surface and in F-silt at depth, while in sandy soils (Spodosols) (valley) carbon is mainly contained in FLF and in F-sand.

FLF is easily decomposed and is replenished in the system by the input of organic litter, which results in greater spatial and seasonal variability than the other fractions of SOM (Christensen, 2000). Greater levels of carbon in FLF near the surface in soils in all three topographic groups (plateau, slope and valley) seem to be directly related to the greatest aggregation being at the surface due to the action of roots and accumulation of leaves that are deposited on the surface (Luizão et al., 2004). Studies show that the aggregates contain labile carbon that is physically protected by action of the microorganisms and that large aggregates protect large amounts of carbon (Amelung and Zech, 1999). Differences in composition and in stability of carbon in the intra-aggregated fractions are believed to be results of recalcitrance and of soil-aggregate protection mechanisms (John et al., 2005; Yamashita et al., 2006).

In the valley bottoms the highest levels of soil carbon were found in FLF (surface) and in F-sand, which agrees with the findings of Roscoe and Machado (2002) who reported the highest proportion of carbon in the sand fraction in sandy soils, while in clay soils (Oxisol and Ultisol) the finer fractions interact strongly with soil organic matter and retain carbon. High carbon content found 
in FLF in valley soil can be explained by the high replacement rate of organic litter. Even though the replacement rate decreases at some times of year, with the smallest production of fine litter occurring in the rainy season, the lower decomposition rate of litter on the soil in the valley bottoms, associated with the burial of part of the litter favors the humification of new organic material that reaches the ground (Luizão, 1989).

Thus, soils in topographically lower areas in the forest are subject to influence from fluctuations in groundwater and the action of fine roots at the soil surface, making carbon available in higher concentrations in the surface layers. Continuous supply of organic material via litterfall and downhill movement of organic material from the Ultisol (slope) to the Spodosol (valley) (due to gravity and the slope of the terrain) can be responsible for rapid replenishment, causing carbon to be present at $42 \%$ to $66 \%$ in FLF (soil surface) and $1 \%$ to $24 \%$ in heavier fractions (F-clay, F-sand and F-silt). Studies on clay Oxisols in tropical areas (Guggenberger et al., 1995; Rangel et al., 2007) have found carbon percentages in sand, silt and clay fractions ranging from $2 \%-4 \%, 39 \%-45 \%$ and $51 \%-59 \%$ of the total soil carbon, which are values close to those found in the present study.

\subsection{Management of Tropical Soils: Storage and Susceptibility in Amazonian Forest}

The soils under Amazonian forests, along the topographic gradient, has great potential to store carbon in depth, being influenced by soil physical properties, soil type and landscape position (Marques et al., 2016). Soils represent a major compartment in biosphere carbon storage, and the stability of soil carbon in forest areas becomes critical when they are cleared or disturbed. Carbon stability affects the total stock, which will tend to a new equilibrium due to changed temperature and other conditions when soil is exposed by deforestation (Fearnside, 2010). Soil is a determining factor both in stabilizing carbon and in the productivity of trees (Hagedorn et al., 2003). In the present study, carbon stocks in soils followed the order: Oxisol (plateau) > Spodosol (valley) > Ultisol (slope), the clay and free light fractions being responsible for the largest stocks.

Deforestation and climate-change effects act directly on carbon stocked in the free light fraction, which is present in greatest proportion in the surface layers. Carbon present in surface layers is more susceptible to mineralization (emission as $\mathrm{CO}_{2}$ if deforested). Carbon contained in the heavy fraction takes more time to be released but this could also be carbon emitted as $\mathrm{CO}_{2}$ or methane over time. In natural ecosystems, organic carbon stocks can be drastically reduced, mainly in tropical regions where high temperatures, high rainfall and the intense biological activity result in rapid decomposition of organic material that is deposited on the ground (Mielniczuk et al., 2003). Carbon is contained in the more labile fractions in surface layers $(0-5,5-10,10-20$ and $20-40 \mathrm{~cm})$ and in heavier fractions in deep layers $(>40 \mathrm{~cm})$. This result suggests the need for preservation of soils under tropical forest because changes in forest cover would decrease carbon stocks due to potential emissions of the labile carbon. This car- 
bon is in the FLF that is present in greater proportions in the surface layers, where it is responsible for $26 \%$ to $90 \%$ of the soil carbon. This carbon can be easily released from the soil due to sensitivity of the free light fraction to inappropriate management (Soares, 2007). Maintenance of the FLF is used as a parameter for evaluating the quality of management systems (Bayer et al., 2001; Conceição et al., 2005).

The fate of carbon stored in the soil under projected global climate change is critical (Davidson and Janssens, 2006; Schultz and Freibauer, 2005; Townsend et al., 1992). Possible release of carbon from the soil matrix is becoming a major concern due to its potential to emit large amounts of $\mathrm{CO}_{2}$ into the atmosphere. Soil carbon stock to 1 -m depth is estimated to total 47 Pg in Brazil's $5 \times 10^{6} \mathrm{~km}^{2}$ Legal Amazon region (Moraes et al., 1995). Soil carbon release could represent a form of positive feedback, contributing to a potential "run away" greenhouse effect (Fearnside, 2010).

If these forests are converted to any other land use exposure of the Oxisols, Ultisols and Spodosols could result in emission of $34 \mathrm{Mg} \mathrm{ha}^{-1}$ of $\mathrm{C}$ contained in the top $2 \mathrm{~m}$ of soil. Spodosols have very strong limitation for agriculture use and it should not be deforested. High proportions of carbon in labile fractions is a characteristic that differentiates the forest ecosystem studied from managed environments, which feature carbon enrichment in the fine fractions. Note that the area of forest studied has amounts of carbon in soil labile fractions that are common in well-preserved areas. Conversion of forest to pasture can reduce stocks of SOC, depending on soil properties, climate and management (Koning et al., 2003). Conversion of forest to other land uses reduces carbon and nitrogen in the soil due to the modification of the input of biomass and litter, especially on the surface (Awiti et al., 2008). Fine fractions in the top layers of soil (0 - 10 $\mathrm{cm}$ ) have been found to increase after removal of native vegetation and exposure of the soil to intensive use (Rangel et al., 2007). Thus, any change in forest cover would promote a gradual increase of carbon in the finer particle size fractions of these soils (F-clay and F-silt), both on the surface and at depth, affecting biological activity in the soil.

Increase of carbon in the heavy fractions implies a lower amount of carbon in forms that are readily available to microorganisms, greater amounts of available carbon being associated with FLF and F-sand (Rangel et al., 2007). The heavy fraction (F-silt, F-clay and F-sand) has a potential C emission of $18.5 \mathrm{Mg} \mathrm{ha}^{-1}$, the clay fraction being especially prominent with a potential emission of $9.2 \mathrm{Mg}$ $\mathrm{ha}^{-1}$ of C. Conversion of forest to pasture causes decrease in total carbon stocks on the order of $40 \%-60 \%$ (Guo and Gifford, 2002).

Removal of the natural vegetation cover would lead to a change over a short time interval in sandy soils, reducing the carbon stocked, since deforestation generally has greater impact on the physical properties of sandy soils (valley bottoms) than in clay soils (plateaus and slopes). Carbon in F-sand has the highest bioavailability, with a much larger amount of particulate matter as compared to F-clay and F-silt (Christensen, 2001). Mineralization experiments show that 
decomposition of carbon associated with these particles is highest in sandy soils, moderate in clay soils and lowest in silt soils (Christensen, 1987). Thus, changes in sandy soils like those we studied under tropical forest would quickly reduce the soil organic carbon associated with FLF and F-sand, which may result in a soil with very low organic matter content and biological activity. Increasing carbon content is necessary in sandy soils from the standpoint of plant growth because the carbon contributes to greater moisture retention, to greater soil aggregation, to increased microbial activity, and consequently to greater sustainability of the soil (Zancanaro, 2004). The lower amount of SOC in sandy soils results in lower soil quality with greater loss of nutrients. These sandy soils should therefore not be managed or altered. In central Amazonia, sandy soils are mainly located near the banks of streams. Unfortunately, changes enacted in 2012 in Brazil's Forest Code (Law No. 12,651 of 25 May 2012) significantly relax legal restrictions on clearing forests near water courses (e.g., Soares-Filho et al., 2014).

The carbon stored in soil fractions points to the need for caution in promoting development programs that reduce areas of tropical forest. Exploiting these areas, coupled with the effect of climate changes, can expose this carbon and lead to substantial losses of these stocks. Stabilization and permanence of carbon in the ecosystem will depend on the relationship between climate and the processes involved in the carbon cycle and, especially the response of these soil carbon stocks to global change (Friedlingstein et al., 2003; Jones et al., 2003).

\section{Conclusion}

Soil organic carbon (SOC) stocks on the plateaus (Oxisol), slopes (Ultisol) and valley bottoms (Spodosol) were $98.4 \pm 7.8 \mathrm{Mg} \cdot \mathrm{ha}^{-1}, 72.6 \pm 5.4 \mathrm{Mg} \cdot \mathrm{ha}^{-1}$ and $81.4 \pm$ 8.9 Mg.ha ${ }^{-1}$, respectively. Soils on plateaus, slopes and valley bottoms store 112.6 $\pm 15 \mathrm{Mg} \cdot \mathrm{ha}^{-1}$ of $\mathrm{C}$ in the free light fraction (FLF), $2.5 \pm 0 \mathrm{Mg} \cdot \mathrm{ha}^{-1}$ of C in the intra-aggregated light fraction (IALF), $40.5 \pm 1.5 \mathrm{Mg} \cdot \mathrm{ha}^{-1}$ of $\mathrm{C}$ in the silt fraction (F-silt), $68.5 \pm 4.2 \mathrm{Mg} \cdot \mathrm{ha}^{-1}$ in the clay fraction (F-clay) and $28.3 \pm 1.4 \mathrm{Mg} \cdot \mathrm{ha}^{-1}$ in the sand fraction (F-sand), totaling $252.4 \pm 22.1 \mathrm{Mg}^{-h^{-1}}$ of carbon. The carbon stocks in soils followed the order: Oxisol (plateau) $>$ Spodosol (valley) $>$ Ultisol (slope), the clay and free light fractions being responsible for the largest stocks. Physical attributes under tropical soils influence the maintenance of carbon through the action of aggregates, pores and soil texture. Spodosols (in valley bottoms) are more susceptible to soil carbon losses, demonstrating the need to preserve forested areas close to Amazonian rivers and streams. Carbon is largely in labile form and near the soil surface, making it liable to release from deforestation or from climate change.

\section{Acknowledgements}

We thank the Large-Scale Atmosphere-Biosphere Experiment in Amazonia (LBA), Instituto Nacional de Pesquisas da Amazônia (INPA), Empresa Brasileira de Pesquisa Agropecuária (EMBRAPA), Conselho Nacional do Desenvolvimento Científico e Tecnológico (CNPq: Proc. 610042/2009-2, 573810/2008-7, 
610042/2009-2) and Fundação de Amparo à Pesquisa do Estado do Amazonas (FAPEAM Proc. 708565) for financial and logistical support.

\section{References}

Amelung, W., \& Zech, W. (1999). Minimisation of Organic Matter Disruption during Particle-Size Fractionation of Grassland Epipedons. Geoderma, 92, 73-85. https://doi.org/10.1016/S0016-7061(99)00023-3

Awiti, A. O., Walsh, M. G., \& Kinyamario, J. (2008). Dynamics of Topsoil Carbon and Nitrogen along a Tropical Forest-Cropland Chronosequence: Evidence from Stable Isotope Analysis and Spectroscopy. Agriculture, Ecosystems and Environment, 127, 265-272. https://doi.org/10.1016/j.agee.2008.04.012

Barros, H. S., \& Fearnside, P. M. (2016). Soil Carbon Stock Changes Due to Edge Effects in Central Amazon Forest Fragments. Forest Ecology and Management, 379, 30-36. https://doi.org/10.1016/j.foreco.2016.08.002

Batjes, N. H., \& Dijkshoorn, J. A. (1999). Carbon and Nitrogen Stocks in the Soils of the Amazon Region. Geoderma, 89, 273-286. https://doi.org/10.1016/S0016-7061(98)00086-X

Bayer, C., Martin-Neto, L., Mielniczuk, J., Pillon, C. N., \& Sangoi, L. (2001). Changes in Soil Organic Matter Fractions under Subtropical No-Till Cropping Systems. Soil Science Society of America Journal, 65, 1473-1478. https://doi.org/10.2136/sssaj2001.6551473x

Campos, D. V. (2003). Use of the 13C Technique and Physical Fractionation of Organic Matter in Soils under Pasture and Sugarcane Coverage in the Atlantic Forest Region. Seropédica. PhD Thesis, Seropédica: Agronomy-Soil Science, Instituto de Agronomia, Universidade Federal Rural do Rio de Janeiro.

Canellas, L. P., Berner, P. G., Silva, S. G., Barros, E., Silva, M., \& Santos, G. A. (2000). Fractions of Organic Matter in Six Soils of a Toposequence in the State of Rio de Janeiro. Pesquisa Agropecuária Brasileira, 35, 133-143. https://doi.org/10.1590/S0100-204X2000000100016

Chauvel, A. (1982). The Oxisol within the Ecosystems of the Experimental Basins of INPA and the Neighboring Region. Acta Amazonica, 12, 38-47.

Chen, C. R., Xu, Z. H., \& Mathers, N. J. (2004). Soil Carbon Pools in Adjacent Natural and Plantation Forests of Subtropical Australia. Soil Science Society of America Journal, 68, 282-291. https://doi.org/10.2136/sssaj2004.2820

Christensen, B. T. (1987). Decomposability of Organic Matter in Particle Size Fractions from Field Studies with Straw Incorporation. Soil Biology \& Biochemistry, 19, 429-435. https://doi.org/10.1016/0038-0717(87)90034-4

Christensen, B. T. (2000). Organic Matter in Soil: Structure, Function and Turnover (95 p). Tjele: DIAS.

Christensen, B. T. (2001). Physical Fractionation of Soil and Structural and Functional Complexity in Organic Matter Turnover. European Journal of Soil Science, 52, 345353. https://doi.org/10.1046/j.1365-2389.2001.00417.x

CIMC (Comitê Interministerial sobre Mudança do Clima) (2008). Plano Nacional sobre Mudança do Clima-PNMC (129 p). Brasília DF: Ministério do Meio Ambiente. http://www.mma.gov.br/estruturas/imprensa/_arquivos/96_01122008060233.pdf

Clapp, C. E., \& Hayes, M. H. B. (1999). Sizes and Shapes of Humic Substances. Soil Science, 164, 777-789. https://doi.org/10.1097/00010694-199911000-00002

Conceição, P. C., Amado, T. J. C., Mielniczuk, J., \& Spagnollo, E. (2005). Soil Quality in Management Systems Evaluated by the Dynamics of Organic Matter and Related 
Attributes. Revista Brasileira de Ciência do Solo, 29, 777-788.

Davidson, E. A., \& Janssens, I. A. (2006). Temperature Sensitivity of Soil Carbon Decomposition and Feedbacks to Climate Change. Nature, 440, 165-173. https://doi.org/10.1038/nature04514

Ekschmitt, K., Liu, M., Vetter, S., Fox, O., \& Wolters, V. (2005). Strategies Used by Soil Biota to Overcome Soil Organic Matter Stability-Why Is Dead Organic Matter Left over in the Soil. Geoderma, 128, 167-176.

https://doi.org/10.1016/j.geoderma.2004.12.024

EMBRAPA (Empresa Brasileira de Pesquisa Agropecuária) (1997). Manual of Methods of Soil Analysis (2nd ed., 212 p). Rio de Janeiro: EMBRAPA, Center National of Soil Research.

Fearnside, P. M. (1989). Forest Management in Amazonia: The Need for New Criteria in Evaluating Development Options. Forest Ecology and Management, 27, 61-79. https://doi.org/10.1016/0378-1127(89)90083-2

Fearnside, P. M. (2003). Conservation Policy in Brazilian Amazonia: Understanding the Dilemmas. World Development, 31, 757-779. https://doi.org/10.1016/S0305-750X(03)00011-1

Fearnside, P. M. (2010). Carbon Stock and Stability in Soils in the Brazilian Amazon. In W. G. Teixeira, D. C. Kern, B. C. Madari, H. N. Lima, \& W. I. Woods, (Eds.), The Dark Earth of the Amazon: Their Characterization and Use of this Knowledge in the Creation of New Areas (pp. 259-263). Manaus: Editora da Universidade Federal do Amazonas (EDUA) and Embrapa Amazônia Ocidental.

Fearnside, P. M. (2016). Brazil's Amazonian Forest Carbon: The Key to Southern Amazonia's Significance for Global Climate. Regional Environmental Change, 1-15. https://doi.org/10.1007/s10113-016-1007-2

Fearnside, P. M., \& Barbosa, R. I. (1998). Soil Carbon Changes from Conversion of Forest to Pasture in Brazilian Amazonia. Forest Ecology and Management, 108, 147-166. https://doi.org/10.1016/S0378-1127(98)00222-9

Fearnside, P. M., \& Leal Filho, N. (2001). Soil and Development in Amazonia: Lessons from the Biological Dynamics of Forest Fragments Project. In R. O. Bierregaard, C. Gascon, T. E. Lovejoy, \& R. Mesquita (Eds.), Lessons from Amazonia: The Ecology and Conservation of a Fragmented Forest (pp. 291-312). New Haven, CT: Yale University Press.

Ferreira, E. A. B. F., Bustamante, M. M. C., Resck, D. V. S., Figueiredo, C. C., Pinto, A. S., \& Malaquias, J. V. (2016). Carbon Stocks in Compartments of Soil Organic Matter 31 Years after Substitution of Native Cerrado Vegetation by Agroecosystems. Revista Brasileira de Ciência do Solo, 40, 1-9. https://doi.org/10.1590/18069657rbcs20150059

Follett, R. F. (2001). Soil Management Concepts and Carbon Sequestration in Cropland Soils. Soil \& Tillage Research, 64, 77-92. https://doi.org/10.1016/S0167-1987(01)00180-5

Friedlingstein, P., Dufresne, J. L., \& Cox, P. M. (2003). How Positive Is the Feedback between Climate Change and the Carbon Cycle? Tellus, 55, 692-700. https://doi.org/10.1034/j.1600-0889.2003.01461.x

Guggenberger, G., Zech, W., \& Thomas, R. J. (1995). Lignin and Carbohydrate Alteration in Particle-Size Separates of an Oxisol under Tropical Pastures Following Native Savanna. Soil Biology \& Biochemistry, 27, 1629-1638.

https://doi.org/10.1016/0038-0717(95)00080-X

Guo, L. B., \& Gifford, R. M. (2002). Soil Carbon Stocks and Land Use Change: A Meta Analysis. Global Change Biology, 8, 345-360. 
https://doi.org/10.1046/j.1354-1013.2002.00486.x

Hagedorn, F., Spinnler, D., Bundt, M., Blaser, P., \& Siegwolf, R. (2003). The Input and Fate of New $\mathrm{C}$ in Two Forest Soils under Elevated $\mathrm{CO}_{2}$. Global Change Biology, 9, 862-872. https://doi.org/10.1046/j.1365-2486.2003.00638.x

Hassink, J., \& Whitmore, A. P. (1997). A Model of the Physical Protection of Organic Matter in Soils. Soil Science Society of America Journal, 61, 131-139. https://doi.org/10.2136/sssaj1997.03615995006100010020x

Houghton, R. A. (2005). Aboveground Forest Biomass and the Global Carbon Balance. Global Change Biology, 11, 945-958. https://doi.org/10.1111/j.1365-2486.2005.00955.x

Jobággy, E. G., \& Jackson, R. B. (2000). The Vertical Distribution of Soil Organic Carbon and Its Relation to Climate and Vegetation. Ecological Applications, 10, 423-436. https://doi.org/10.1890/1051-0761(2000)010[0423:TVDOSO]2.0.CO;2

John, B., Yamashita, T., Ludwing, B., \& Fless, J. (2005). Storage of Organic Carbon in Aggregate and Density Fractions of Silty Soils under Different Types of Land Use. Geoderma, 128, 63-79. https://doi.org/10.1016/j.geoderma.2004.12.013

Jones, C., Cox, P., \& Huntingford, C. (2003). Uncertainty in Climate-Carbon Cycle Projections Associated with the Sensitivity of Soil Respiration to Temperature. Tellus, 55, 642-648. https://doi.org/10.1034/j.1600-0889.2003.01440.x

Koning, G. H. J., Veldkamp, E., \& Lopez-Ulloa, M. (2003). Quantification of Carbon Sequestration in Soils Following Pasture to Forest Conversion in North-Western Ecuador. Global Biogeochemical Cycles, 17, 1098-1108.

https://doi.org/10.1029/2003GB002099

Lavelle, P., Bignel, L. D., Lepage, M., Wolters, V., Roger, P., Ineson, P., Heal, O. W., \& Dhillion, S. (1997). Soil Function in a Changing World: The Role of Invertebrate Ecosystem Engineers. European Journal of Soil Biology, 33, 159-193.

Lopez-Ulloa, M., Veldkamp, E., \& Koning, G. H. J. (2005). Soil Carbon Stabilization in Converted Tropical Pastures and Forests Depends on Soil Type. Soil Science Society of America Journal, 69, 1110-1117. https://doi.org/10.2136/sssaj2004.0353

Luizão, F. J. (1989). Litter Production and Mineral Element Input to the Forest Floor in a cEntral Amazonian Forest. GeoJournal, 19, 407-417. https://doi.org/10.1007/BF00176910

Luizão, R. C. C., Luizão, F. J., Paiva, R. Q., Monteiro, T. F., Souza, L. S., \& Kruijt, B. (2004). Variation of Carbon and Nitrogen Cycling Processes along a Topographic Gradient in a Central Amazonian Forest. Global Change Biology, 22, 592-600. https://doi.org/10.1111/j.1529-8817.2003.00757.x

Marques, J. D. O., Luizão, F. J., Teixeira, W. G., Vitel, C. M., \& Marques, E. M. A. (2016). Soil Organic Carbon, Carbon Stock and Their Relationships to Physical Attributes Under Forest Soils in Central Amazonia. Revista Arrore, 40, 197-208. https://doi.org/10.1590/0100-67622016000200002

Marques, J. D. O., Luizão, F. J., Teixeira, W. G., \& Ferreira, S. J. F. (2012). Variations of Dissolved Organic Carbon and Soil Physical Attributes under Different Land Use Systems in Central Amazonia. Revista Brasileira de Ciência do Solo, 36, 611-622. https://doi.org/10.1590/S0100-06832012000200030

Marques, J. D. O., Teixeira, W. G. T., Reis, A. M., Cruz-Junio, O. F., \& Martins, G. C. (2008). Evaluation of the Hydraulic Conductivity of the Saturated Soil Using Two Laboratory Methods in a Toadsequence with Different Vegetation Cover in the Amazon Low. Acta Amazonica, 38, 193-206.

https://doi.org/10.1590/S0044-59672008000200002

Marques, J. D. O., Teixeira, W. G., Reis, A. M., Junior, O. F. C., Batista, S. M., \& Afonso, 
M. A. C. B. (2010). Chemical, Physical-Hydrological and Mineralogical Attributes of the Clay Fraction in Soil of the Lower Amazon: Serra de Parintins. Acta Amazonica, 40, $1-12$.

Mielniczuk, J., Bayer, C., Vezzani, F. M., Lovato, T., Fernandes, F. F., \& Debarba, L. (2003). Management and Crops and Their Relationship with Carbon and Soil Nitrogen Stocks. In N. Curi, J. J. Marques, L. R. G. Guilherme, J. M. Lima, A. S. Lopes, \& V. H. Alvarez (Eds.), Topics in Soil Science (pp. 209-248). Minas Gerais: Brazilian Society of Soil ScienceViçosa.

MMA (Ministerio do Meio Ambiente) (2009). The Brazilian REDD Strategy (29 p). Brasília DF: MMA.

http://www.mma.gov.br/estruturas/168/_publicacao/168_publicacao19012010035219.pdf

Moraes, J. L., Cerri, C. C., Melillo, J. M., Kicklighter, D., Neil, C., Skole, D. L., \& Steudler, P. A. (1995). Soil Carbon Stocks of the Brazilian Amazon Basin. Soil Science Society of America Journal, 59, 244-247. https://doi.org/10.2136/sssaj1995.03615995005900010038x

Nogueira, E. M., Yanai, A. M., Fonseca, F. O. R., \& Fearnside, P. M. (2015). Carbon Stock Loss from Deforestation through 2013 in Brazilian Amazonia. Global Change Biology, 21, 1271-1292. https://doi.org/10.1111/gcb.12798

Oliveira, D. M. S., Paustian, K., Davies, C., Cherubin, M. R., Franco, A. L. C., Cerri, C. C., \& Cerri, C. E. P. (2016b). Soil Carbon Changes in Areas Undergoing Expansion of Sugarcane into Pastures in Brazil. Agriculture, Ecosystems \& Environment, 228, 38-48. https://doi.org/10.1016/j.agee.2016.05.005

Oliveira, F. E. R., Oliveira, J. M. O., \& Xavier, F. A. S. (2016a). Changes in Soil Organic Carbon Fractions in Response to Cover Crops in an Orange Orchard. Revista Brasileira de Ciência do Solo, 40, 1-12. https://doi.org/10.1590/18069657rbcs20150105

Passos, R. R., Ruiz, H. A., Cantarutti, R. B., \& Mendonça, E. S. (2007). Organic Carbon and Nitrogen in Aggregates of an Oxisol under Two Vegetation Cover. Revista Brasileira de Ciência do Solo, 31, 1109-1118. https://doi.org/10.1590/S0100-06832007000500026

Pinheiro, E. F. M., Pereira, M. G., \& Anjos, L. H. C. (2004). Aggregate Distribution and Soil Organic Matter under Different Tillage System for Vegetable Crops in a Red Latosol from Brazil. Soil \& Tillage Research, 77, 79-84.

https://doi.org/10.1016/j.still.2003.11.005

Quesada, C. A., Phillips, O. L., Schwarz, M., Czimczik, C. I., Baker, T. R., Patiño, S., Fyllas, N. M., Hodnett, M. G., Herrera, R., Almeida, S., Alvarez Dávila, E., Arneth, A., Arroyo, L., Chao, K. J., Dezzeo, N., Erwin, T., Di Fiore, A., Higuchi, N., Honorio Coronado, E., Jimenez, E. M., Killeen, T., Lezama, A. T., Lloyd, G., López-González, G., Luizão, F. J. et al. (2012). Basin-Wide Variations in Amazon Forest Structure and Function Are Mediated by Both Soils and Climate. Biogeoscience, 9, 2203-2246. https://doi.org/10.5194/bg-9-2203-2012

Rangel, O. J. P., Silva, C. A., \& Guimarães, P. T. G. (2007). Stock and Fractions of the Organic Matter of Latosol Cultivated with Coffee in Different Planting Spacings. Revista Brasileira de Ciência do Solo, 31, 1341-1353. https://doi.org/10.1590/S0100-06832007000600013

Ranzani, G. (1980). Identification and Characterization of Some Soils of the Experimental Station of Tropical Forestry. Acta Amazonica, 1, 7-51.

Roscoe, R., \& Buurman, P. (2000). Disruption of Soil Aggregates by Varied Amount of Ultrasonic Energy in Fractionation of Clay Latosol. European Journal of Soil Science, 51, 445-454. https://doi.org/10.1046/j.1365-2389.2000.00321.x

Roscoe, R., \& Machado, P. L. O. A. (2002). Soil Physical Fractionation in Organic Matter 
Studies (86 p). Dourados: Embrapa Agropecuária Oeste.

Schultz, E. D., \& Freibauer, A. (2005). Unlocking Carbon from Soils. Nature, 237, $205-$ 206.

Signor, D., Zani, C. F., Paladini, A. A., Deon, M. D., \& Cerri, C. E. P. (2014). Carbon Stocks and Soil Organic Matter Quality in Areas Cultivated with Sugarcane. Revista Brasileira de Ciência do Solo, 38, 1402-1410. https://doi.org/10.1590/S0100-06832014000500005

Silva, J. R., Silva, D. J., Gava, C. A. T., Oliveira, T. C. T., \& Freita, M. S. C. (2016). Carbon in Humic Fractions of Organic Matter in Soil Treated with Organic Composts under Mango Cultivation. Revista Brasileira de Ciência do Solo, 40, 1-11. https://doi.org/10.17666/319114/2016

Sisti, C. P. J., Santos, H. P., Kohhan, R., Albes, B. J. R., Urquiaga, S., \& Bodey, R. M. (2004). Change in Carbon and Nitrogen Stocks in Soil under 13 Years of Conventional or Zero Tillage in Southern Brazil. Soil and Tillage Research, 76, 39-58.

https://doi.org/10.1016/j.still.2003.08.007

Soares, R. (2007). Aggregation and Distribution of Organic Matter in Native Amazonian Soils of Central Amazonia (107 p). Masters Dissertation in Geosciences, Niterói: Universidade Federal Fluminense.

Soares-Filho, B. S., Rajão, R., Macedo, M., Carneiro, A., Costa, W., Coe, M., Rodrigues, H., \& Alencar, A. (2014). Cracking Brazil's Forest Code. Science, 344, 363-364. https://doi.org/10.1126/science.1246663

Sohi, S., Mahieu, N., Arah, J. R. M., Powlson, D. S. P., Madari, B., \& Gaunt, J. L. (2001). Procedure for Isolating Soil Organic Matter Fractions Suitable for Modeling. Soil Science Society of America Journal, 65, 1121-1128. https://doi.org/10.2136/sssaj2001.6541121x

Souza, R. F., Brasil, E. P. F., Figueiredo, C. C., \& Leandro, W. M. (2015). Soil Organic Matter Fractions in Preserved and Disturbed Wetlands of the Cerrado Biome. Revista Brasileira de Ciência do Solo, 39, 222-231. https://doi.org/10.1590/01000683rbcs20150048

Tisdall, J. M., \& Oades, J. M. (1982). Organic Matter and Water-Stable Aggregates in Soils. European Journal of Soil Science, 33, 141-163. https://doi.org/10.1111/j.1365-2389.1982.tb01755.x

Townsend, A. R., Vitousek, P. M., \& Holland, E. A. (1992). Tropical Soils Could Dominate the Short-Term Carbon Cycle Feedbacks to Increase Global Temperatures. Climatic Change, 22, 293-303. https://doi.org/10.1007/BF00142430

Volkoff, B., Cerri, C. C., \& Melfi, J. A. (1984). Humus and Mineralogy of the Surface Horizons of Three High Altitude Field Soils of the Minas Gerais, Paraná e Santa Cataria. Revista Brasileira de Ciência do Solo, 8, 277-283.

Von Lutzow, M., Kogel-Knabner, I., Ekschmitt, K., Matzner, E., Guggenberger, G., \& Marschners, B. (2006). Stabilization of Organic Matter in Temperate Soils: Mechanisms and Their Relevance under Different Soil Conditions. European Journal of Soil Science, 57, 426-445. https://doi.org/10.1111/j.1365-2389.2006.00809.x

Waterloo, M. J., Oliveira, S. M., Drucker, D. P., Nobre, A. D., Cuartas, L. A., Hodnett, M. G., Langedijk, I., Wilma, W. P., Tomasella, J., Araújo, A. C., Pimentel, T. P., \& Munera, J. C. (2004). Export of Organic Carbon in Runoff from an Amazonian Rainforest Blackwater Catchment. Hydrological Processes, 10, 1-35.

Yamashita, T., Flessa, H., John, B., Helfrich, M., \& Ludwing, B. (2006). Organic Matter in Density Fractions of Water-Stable Aggregates in Silty Soils: Effect of Land Use. Soil Biology \& Biochemistry, 38, 3222-3234. https://doi.org/10.1016/j.soilbio.2006.04.013 
Zancanaro, L. (2004). Manejo de solos arenosos. Boletim Técnico da Soja. Rondonópolis: Fundação MT.

Zech, W., Senesi, N., Guggenberger, G., Kaiser, K., Lehmann, J., Miano, T. M., Miltner, A., \& Schroth, G. (1997). Factors Controlling Humification and Mineralization of Soil Organic Matter in the Tropics. Geoderma, 79, 117-161.

https://doi.org/10.1016/S0016-7061(97)00040-2

Submit or recommend next manuscript to SCIRP and we will provide best service for you:

Accepting pre-submission inquiries through Email, Facebook, LinkedIn, Twitter, etc. A wide selection of journals (inclusive of 9 subjects, more than 200 journals)

Providing 24-hour high-quality service

User-friendly online submission system

Fair and swift peer-review system

Efficient typesetting and proofreading procedure

Display of the result of downloads and visits, as well as the number of cited articles

Maximum dissemination of your research work

Submit your manuscript at: http://papersubmission.scirp.org/

Or contact ojf@scirp.org 